\title{
FARMERS' ATTITUDES AND PROBLEMS ASSOCIATED WITH THE ADOPTION OF CAPE SAINT PAUL RESISTANT COCONUT HYBRID IN THE WESTERN REGION OF GHANA
}

\author{
E. L. OKORLEY ${ }^{1}$ and E. HAIZEL ${ }^{2}$ \\ ${ }^{1}$ Lecturer in Agricultural Extension, School of Agriculture, University of Cape Coast, Ghana. \\ E-mail: leokorley@yahoo.com \\ ${ }^{2}$ Teaching Assistant Department of Agricultural Extension and Economics, School of Agriculture, University of Cape \\ Coast, Ghana.
}

\begin{abstract}
The Coconut (Cocos nucifera) is a very important economic crop in Ghana. But its production is currently running down due to the Lethal Yellowing-type disease commonly known as Cape St. Paul Wilt Disease (CSPWD). To avert this situation the Ministry of Food and Agriculture in Ghana introduced a hybrid coconut (SGD $\times$ VTT) believed to show tolerance to the CSPWD to farmers. The study assessed the problems and attitudes of farmers in the West Ghana towards the adoption of the hybrid. This descriptive study used interviewed responses from selected farmers in the western region of Ghana where the CSPWD is an issue. The results showed that the farmers were aware of CSPWD, its symptoms and the resistant hybrid. The farmers showed favourable attitudes to rejuvenate their farms with the hybrid, but are sceptical about their success in the long-run. Thus, only few had planted the hybrid. Farmers interested in the hybrid expressed common problems of getting true-to-type seedlings at the right time and at a reasonable cost. Salvaging the coconut industry in Ghana will need concerted efforts from MoFA, Crop Research Institute and agro-based coconut industries to support and promote proven CSPWD-resistant coconut varieties among farmers.
\end{abstract}

Key words : Coconut, Cape Saint Paul Wilt Disease (CSPWD), Adoption, Resistant Coconut Hybrid, Ghana.

RESUME

ATTITUDE DES PAYSANS ET PROBLĖMES LIÉS À L'ADOPTION DE L'HYBRIDE DE COCOTIER RÉSISTANT À LA MALADIE DU JAUNISSEMENT MORTEL

La noix de coco (Cocos nucifera) est une importante production de rente au Ghana. Mais actuellement, sa production est en baisse constante à cause de la maladie du jaunissement mortel connue sous le nom de maladie desséchante du Cap St-Paul. Pour prévenir cette situation, le Ministère de l'Alimentation et de l'Agriculture a introduit un hybride de cocotier (SGD x VTT) résistant à la maladie. L'étude a évalué l'attitude des paysans de l'Ouest ghanéen quant à l'adoption de l'hybride. Elle a consisté en une enquête menée auprès de ces paysans. Les résultats ont montré qu'ils avaient connaissance de la maladie et de l'hybride résistant. Ils se sont montrés favorables à la replantation de leurs vergers avec ledit matériel végétal, mais ont été sceptiques quant au succès à long terme. En effet, peu de paysans ont cultivé ce matériel. Ceux intéressés par l'innovation ont souligné les difficultés d'obtention des plants à temps et à un coût abordable. La sauvegarde de l'industrie de la noix de coco au Ghana nécessitera des effets concertés du Ministère de l'Agriculture, de la Recherche agricole et des Opérateurs de la filière pour assurer la promotion de l'hybride auprès des paysans.

Mots clés : coco, jaunissement mortel, adoption, hybride résistant, Ghana. 


\section{INTRODUCTION}

Coconut (Cocos nucifera) has lost its origin to antiquity though some believe it may come from either America (tropical South America and the Antilles), Southeast Asian peninsular (probably Malaysia) or South Africa. The crop is believed to have gotten to Ghana by ocean current and through the activities of missionaries in 1912 (Will, 1962). Coconut was first cultivated in Ghana as an estate crop at Keta, in the NorthWestern part of Ghana (Will, I.c. 1962). The commercialisation of the crop led to its expansion into the Western Region of Ghana where the climate is more conducive for its cultivation (Chona and Adansi, 1970). The land area under coconut cultivation in Ghana is estimated as 43000 ha (Dery et al., 1995).

The coconut, like oil palm is an economic crop in Ghana. The crop serves several economic purposes ranging from the provision of fuel, food, indigenous building materials to industrial raw materials including fibre and oil. Coconut was a good source of income in Ghana until the 1980s when the Cape Saint Paul Wilt Disease (CSPWD) became a serious national issue. The
CSPWD is one disease known to have caused a great setback to the coconut industry where it had occurred (Dickson, 1964). The CSPWD was first reported in Ghana in 1964 at Weh, a coastal town in the Cape Saint Paul in the Volta Region of Ghana. And, since this time, there has been progressive decline in coconut trees and yields in Ghana (Ofori and Nkansa-Poku, 1995). The disease has destroyed about 3500 ha of coconut in the western region of Ghana and about 90 percent of the country's coconut plantations are now at risk, as the incidence of the disease is countrywide (Ofori and Nkansa-Poku, 1995).

The CSPWD which is believed to be caused by a phytoplasma-like organisms (Beakbane et al., 1972 ; Dollet and Giannotti, 1976) and transmitted by Myndus Spp (crudus and adiopodoumeensis) (Dery et al., 1995 ; Tsai, 1977 ) is characterised by premature dropping of nuts ; blackening (necrosis) of the tips of spikelets in both the opened and closed inflorescence ; profuse yellowing of fronds and eventual browning; and finally toppling over of the crown leaving the characteristic 'telegraphic poles' as shown in the figure below (Ofori and Nkansa-Poku, 1995).

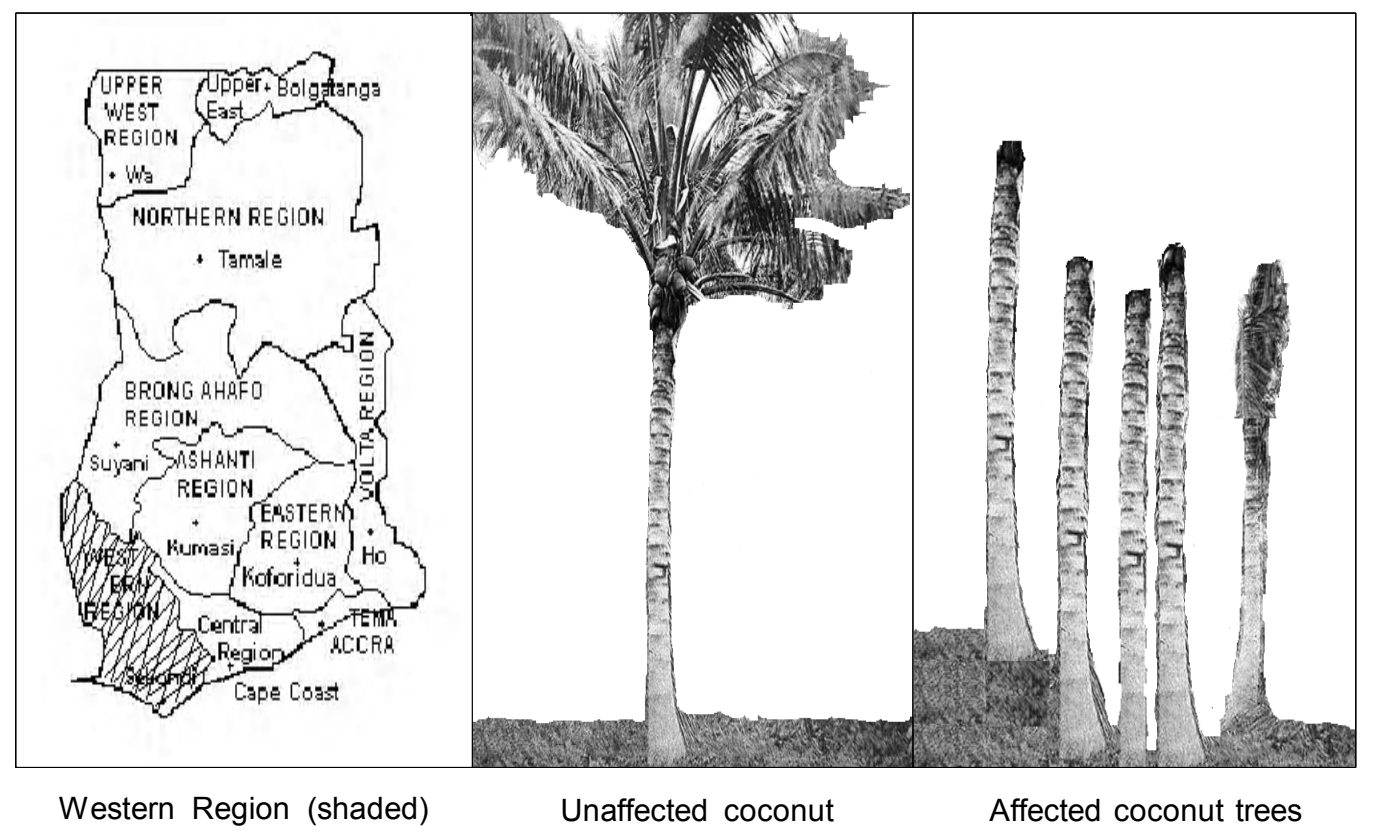

Figure 1 : Coconut trees (Source : Mariau et al., 1998).

Cocotiers sains et cocotiers malades.. 
Efforts to control the CSPWD have been at slower pace, considering the rate of spread and devastation of the disease. For example, between 1983 and 1989 the disease spread widely within the Central and Western Regions of Ghana (Ofori and Nkansa-Poku, 1995). The recommended methods for controlling the diseases are 'hot fogging' and cutting out of all coconut trees believed to be infected by the disease (Dery and Philippe, 1995), and replanting with resistant hybrid coconuts (Mariau et al, 1998). The methods either aim at reducing the population of the insect vector or preventing re-infestation by cutting and replacing with CSPWD-resistant varieties.

A hybrid coconut, which is a cross between the Vanuatu Tall (VTT) and the Sri Lanka Green Dwarf (SGD), was introduced in 1996 to farmers in Ghana as CSPWD-tolerant variety. The Sri Lanka Green Dwarf (SGD) so far is the only variety that has been reported to have shown complete resistance to the CSPWD (Nipah, 2000). The hybrid has also been reported to have shown resistance to the CSPWD and exhibited comparatively good qualities such as higher yields, early maturity and appreciable oil content over the local West African Tall (WAT) variety. Nipah (2000) reported that though the inflorescence of SGD gives fewer number of female flowers compared to WAT it tends to produce higher proportion of flowers and nuts than the WAT.

However, since the introduction of the hybrid coconut for rehabilitation of coconut farms in Ghana little has been done to assess farmers' response and attitude in the adoption process. The aim of the study was to provide empirical data to describe and understand farmers' response and problems in rehabilitating their farms with the hybrid coconut.

\section{MATERIAL AND METHODS}

A descriptive survey method was used for the study. Coconut farmers in three districts in the Western Region of Ghana provided the data in this study. The districts were Ahanta West, Shama-Ahanta East, and Nzema East. The Western Region is one of the administrative regions in Ghana, and lies in the South Western coastal line of Ghana, stretching from $5^{\circ} \mathrm{N}$ to $6^{\circ}$ $\mathrm{N}$ and $2^{\circ} \mathrm{W}$ to $3^{\circ} \mathrm{W}$. The region is mainly occupied by fishing communities, but farming is the major occupation with coconut, 'once upon a time' a sign of wealth.
Sixty coconut farmers were interviewed in the study. A combination of purposive and random sampling methods was used to select the farmers from the districts. Three districts were purposively selected out of a total of 11 districts in the Western Region based on intensity of coconut cultivation. From the districts, 20 coconut farmers were randomly selected from five popular coconut growing towns in each of the three districts. Data were collected through interviews using a validated semi-structured interview schedule. The data were computed with the SPSS ${ }^{\times}$statistical software and presented using descriptive statistic such as frequencies, percentages and means.

\section{RESULTS AND DISCUSSION}

The results show that 90 percent of the farmers interviewed were between 40 and 89 years old, which show an ageing industry. The farmers were predominantly (85\%) males, which is characteristic to most plantation farming in Ghana. Women in such communities tend to be more in coconut processing and marketing. A majority $(73 \%)$ of the farmers in the study were very experienced ( $\geq 10$ years) but were less educated. Most of them (86.7\%) had cultivated between 1 and 5 hectares of coconut, and about half ( $54 \%$ ) of them claimed coconut farming was their major source of income. Coconut production is a small-holding farming business in Ghana and land area under cultivation is usually between 05 - 5ha (OwasuNipah and Dery, 1994).

\section{AWARENESS OF CSPWD AND PERCEIVED DAMAGE IT HAS CAUSED TO FARMS}

A majority of the farmers (95\%) were aware of the CSPWD. The farmers (61\%) who had stayed in the coconut business for longer period, on the average, had been aware of the disease for 10 years. It was deduced that the farmers became aware of the disease in the late 1980s and early 1990s when the incidence of the disease was rampant in Ghana, especially, in the Central and Western Regions. During the period, the Ministry of Food and Agriculture (MoFA) did a lot of awareness campaign and worked with farmers in assessing the extent of 
damages caused by the disease. Thus, majority of the farmers either became aware of the disease through extension agents of MoFA (37\%) or through their personal observation $(33 \%)$ of its devastation (table
1). The farmers $(91.5 \%)$ knew what the symptoms of the CSPWD are and a good number of them $(66 \%)$ said they had once experienced a great damage from the disease in the past.

Table 1: Awareness of CSPWD and the perceived damage to farms (57).

Connaissance de la maladie et dégâts causés dans les vergers.

\begin{tabular}{|c|c|c|}
\hline Parameter & Frequency & Percent \\
\hline \multicolumn{3}{|l|}{ Source of information on CSPWD } \\
\hline Extension Agents/MoFA & 21 & 36.9 \\
\hline Other farmers & 13 & 22.8 \\
\hline Personal observation & 19 & 33.3 \\
\hline Others (Banks, friends, relations etc) & 4 & 7.0 \\
\hline Total & 57 & 100.0 \\
\hline \multicolumn{3}{|l|}{ Years of Awareness } \\
\hline $1-5$ & 18 & 31.5 \\
\hline $5-10$ & 17 & 29.8 \\
\hline $11-15$ & 10 & 17.5 \\
\hline $16-20$ & 9 & 15.8 \\
\hline $21-25$ & 3 & 5.3 \\
\hline Total & 57 & 100.0 \\
\hline \multicolumn{3}{|l|}{ Extent of Damage } \\
\hline Great & 31 & 66.0 \\
\hline Moderate & 7 & 14.9 \\
\hline Slight & 9 & 19.1 \\
\hline Total & 47 & 100.0 \\
\hline
\end{tabular}

\section{AWARENESS OF THE CSPWD- RESISTANT HYBRID}

A number of the farmers $(61.5 \%)$ had been introduced to the hybrid variety (SGD $x$ VTT) by MoFA through their extension agents and also by diffusion from other farmers, local FM radio station and relations. Hence, many of the farmers $(85 \%)$ claimed to be aware of the hybrid. The Ministry of Food and Agriculture in Ghana embarked on a campaign for farmers to consider using CSPWD-resistant varieties in the earlier 1990s when it became clear that the only effective way to control the disease is to use tolerant varieties or hybrids. Thus, in Ghana, the Vanuatu Tall, a hybrid between the WAT and the Malayan Yellow Dwarf, and even better still, a hybrid between the Vanuatu Tall and Sri Lanka Green Dwarf (SGD x VTT) were promoted among farmers as CSPWD-resistant varieties (Mariau et al., 1998).

\section{PERCEIVED ADVANTAGES OF THE HYBRID TO FARMER}

The hybrid besides being tolerant to the CSPWD is noted to start bearing between 3 to 4 years as against the WAT which takes up to 7 years to fruit. Most of the farmers (70\%) through their own experience or probably from demonstrations and fieldtrips organised by MoFA, agreed that the hybrid variety bears earlier and produces higher number of bunches and fruits than the local variety. Frémond and de Lamothe (1971) found that the hybrid coconut produces more bunches than the local tall variety. The authors found that the hybrid recorded an average yield of 120 nuts per tree which is significantly more than that of the tall local variety (Frémond and de Lamothe, 1971).

A little above half ( $53.3 \%$ ) of the farmers feel the local coconut variety is better than the hybrid 
in terms of oil production, though it is argued that the hybrid is comparable to the local variety in terms of oil content. But, oil content of the hybrid was generally not a problem to the farmers (94.9\%; table 2). Cooke (1936) long time ago has reported that the oil content of coconut is inversely related to the size of the nut. This goes to support the argument that the hybrid coconut which has smaller nuts is more likely to have higher oil content. It was observed that many of the farmers who had cultivated the hybrid had not yet harvested and processed for oil. Thus, their responses were mainly based on feelings or what they have heard or seen from others including MoFA and the Oil Palm Research Institute (OPRI) in Ghana. The results also show that a large number of the farmers $(75 \%)$ were of the opinion that the planting and cultural methods (lining and pegging and maintenance) recommended for the hybrid variety is more demanding than the local variety.

Table 2 : Perceived advantages of the hybrid coconut $(n=60)$.

Avantages du cocotier hybride selon les paysans $(n=60)$.

\begin{tabular}{lcc}
\hline Advantages & $\begin{array}{c}\text { Number of farmers who } \\
\text { agreed }\end{array}$ & Percent \\
\hline It starts bearing early & 52 & 86.7 \\
Number of coconut per plant is higher & 50 & 83.3 \\
Number of bunches produced are higher & 46 & 76.7 \\
Oil content of copra is higher & 28 & 46.7 \\
The lining and pegging methods used for the & 15 & 25.0 \\
hybrid is easier & & \\
\hline
\end{tabular}

\section{FARMERS'ATTITUDE TOWARDS THE HYBRID COCONUT}

Generally, the farmers showed favourable attitude towards the hybrid-coconut (table 3). A great number of the farmers (93.2\%) believed that the hybrid coconut has a better economic value than the local tall variety. The farmers (90 $\%$ ) expressed the feeling that they like the hybrid and are prepared to expand their farms with the hybrid and also recommend it to other farmers.
However, there was scepticism among a considerable number of the farmers (59.2\%) that the hybrid would eventually yield to the disease in the long-run. This later feeling of the farmers may have stemmed from the fact that in Ghana, the tolerance of the hybrid (SGD $x$ VTT) has not been tested on a large scale production (Mariau, et al., 1998). This could explain why only few of the farmers $(25 \%)$ had actually expanded or rehabilitated their farms with the hybrid.

Table 3 : Farmers' attitude towards the hybrid coconut $(n=60)$.

Attitude des paysans vis-à-vis de l'hybride de cocotier $(\mathrm{n}=60)$.

\begin{tabular}{lcc}
\hline Farmers who: & $\begin{array}{c}\text { Number of farmers who } \\
\text { agreed }\end{array}$ & Percent \\
\hline $\begin{array}{l}\text { - Believe the they will get more economic benefit from the } \\
\text { hybrid }\end{array}$ & 55 & 93.2 \\
- Like the hybrid coconut & 54 & 90.0 \\
- Would recommend the hybrid coconut to other farmers & 54 & 90.0 \\
- Would like to expand their plantation with the hybrid coconut & 45 & 75.0 \\
- Have found more information about the hybrid & 34 & 56.7 \\
- Were afraid the hybrid may be affected by the disease & 35 & 59.3 \\
- Had planted some hybrid coconuts on the farms & 15 & 25.0 \\
\hline
\end{tabular}




\section{PROBLEM ASSOCIATED WITH THE HYBRID COCONUT}

Only few (5.1\%) to about half (50\%) of the farmers indicated some problems with the use of the hybrid coconut (table 4). The frequently mentioned problems were high cost of the hybrid seedlings (50\%) ; difficulty in the acquisition of the hybrid (46.7\%) ; difficulty in identifying the hybrid seedling from other varieties (43.3\%); and in some cases high cost of transportation, where long distances are involved (38.3\%). Despite the introduction of the hybrid to farmers, the MoFA has not commercialised the production of the hybrid seedlings to a level where farmers can get the true-to-type lines, as and when they want them and at reasonable overall cost. Thus farmers who were interested in the hybrid had difficulties in getting adequate seedlings from MoFA who had been the main source of the hybrid.

Table 4: Problems associated with the adoption of the hybrid coconut $(n=60)$.

Problèmes liés à l'adoption de l'hybride de cocotier $(\mathrm{n}=60)$.

\begin{tabular}{lcc}
\hline Problem & $\begin{array}{c}\text { Number of farmers who } \\
\text { agreed }\end{array}$ & Percent \\
\hline Acquisition of the hybrid coconut seedlings & 28 & 46.7 \\
Cost of the hybrid coconut seedlings & 30 & 50.0 \\
Cost of transporting the hybrid coconut seedlings & 23 & 38.3 \\
Identification of the hybrid coconut seedlings & 26 & 43.3 \\
Planting method for the hybrid coconut & 8 & 13.3 \\
Oil content and extraction from the hybrid coconut & 3 & 5.1 \\
\hline
\end{tabular}

\section{CONCLUSION}

The results show that Coconut farmers in the Western Region of Ghana are aware of CSPWD, its symptoms and the CSPWD-resistant hybrid available in the country. Coconut farmers in the study region have favourable attitude towards the hybrid for its superior qualities. However, the farmers are suspicious of its long term tolerance to the CSPWD, and coupled with other problems, very few are cultivating the hybrid. The most common problems the farmers are facing are how they can get the 'pure' hybrid (certainty) seedlings at the right time and at a reasonable cost for cultivation. There is the need to intensify extension with large scale plantation demonstrations to increase the confidence of farmers in the hybrid varieties in the Ghana. It is also important, for a start, for MoFA and the Crop Research Institute (CRI) of Ghana to established research and seedling production centres where farmers can get certified true-to-type CSPWDresistant coconut varieties. It is suggested that agro-industries which use coconut products as raw materials need to go into large-scale coconut farming with out-grower schemes to salvage the industry. The out-grower schemes will provide some level of security and encourage farmers to use and expand their farms with the recommended hybrid varieties.

\section{REFERENCES}

BEAKBANE (A. B.), (C. H. W.) SLATER, and (A. F.) POSNETTE. 1972. Mycoplasmas in the phloem of coconut, Cocos nucifera L. with lethal yellowing disease. Journal of Horticultural Science $47: 265$.

CHONA (B. L.) and (M. A.) ADANSI. 1970. Coconut in Ghana. Crops Research Institute Bulletin No. 3. Council for Scientific and Industrial Research (CSIR) Kwadaso, Kumasi GHANA.

COOKE (F. C.). 1936. The Coconut Indistry in the Philippine Island. Department of Agric. Sc. and Farm Management Sc. Bulletin No. 23

DERY (S.K.), (Y.P.) N'CHO, (A.) SANGARE and (E.D.) ARKHURST. 1997. Cape St. Paul Wilt Disease resistance screening and prospects for rehabilitating the coconut industry in Ghana. In (S.J) Eden-Green and (F.) Ofori, (Ed.). Proceedings of an international Workshop on Lethal Yellowing-Like diseases of coconut. Elmina, Ghana, November 1995. Natural Resources Institute, Chatham, UK 147- 152 p. . 
DERY (S. K.), (R) PHILIPPER and (D.) MARIAU. 1997. Results of preliminary observations on Auchenorrhynca (Homoptera) suspected vectors of lethal yellowing disease in Ghana. In : (S.J) Eden-Green and (F.) Ofori, (Ed.) Proceedings of an International Workshop on Lethal Yellowing-like diseases of coconut. Elmina, Ghana, November 1995, Natural Resources Institute, Chatham, UK. $19 p$.

DERY (S. K.), (R.) PHILIPPER. 1995. Results of preliminary study of the epidemiology of the Cape St Paul Wilt disease of coconut in Ghana. In (S.J) Eden-Green and (F.) Ofori, (Ed.). Proceedings of an International Workshop on Lethal Yellowing-like diseases of coconut. Elmina, Ghana, November 1995, Natural Resources Institute, Chatham, UK. 14p.

DICKSON (K. B.) 1964. Development of the copra industry in Ghana. The Tropical Journal of Agriculture $19: 27$ - 34 .

MARIAU (D.), (S. K.) DERY, ( A.) SANGARÉ, (Y.P.) N'CHO and (R.) PHILIPPE. 1998. Coconut lethal yellowing disease in Ghana and planting material tolerance, Palm \& Cycad Societies of Florida, Inc. Retrieved December 15, 2003, from http:// www.plantapalm.com/vpel pestsndiseases/vpe_coconutly2.htm.
NIPAH (J. O.). 2000. «Some characteristics of the Sri Lanka Green Dwarf (SGD) : a variety resistant to the Cape Saint Paul Wilt Disease of coconut.» Journal of the Ghana Science Association 2(2) : 88 - 93.

OFORI (F.) and (J.) NKANSAH-POKU. 1997. Cape St. Paul Wilt disease of coconut in Ghana: History of its occurrence and spread. In: (S.J) Eden-Green and (F.) Ofori, (Ed.). Proceedings of an International Workshop on Lethal Yellowing-like diseases of coconut, Elmina, Ghana, November 1995. Natural Resources Institute, Chatham, UK. 27-32p..

OWASU-NIPAH (J.) and (S.K.) DERY.1994. Coconut Breeding Programme in Ghana In : (P.A.) Batugal and (V.) Ramanatha Rao (Ed.). Coconut Breeding. Paper presented at a Workshop on standardisation of coconut breeding research techniques, June 1941, Port Bouet, Cote d'Ivoire. IPGRI - APO, Serdang, Malaysia. 114 -118p.

TSAI (J. H.).1977. «Attempts to transmit lethal yellowing of coconut palm by the planthopper Haplaxius crudus.» Plant Dis. Rep 61: 304-307.

WILLS (J. B.). 1962. Agriculture and Land Use in Ghana. London, Oxford University Press, 353-354p. 